\title{
ONE-POT ELECTROCHEMICAL FABRICATION OF SnO-REDUCED GRAPHENE OXIDE ELECTRODES FOR AMPEROMETRIC SENSING OF DOPAMINE
}

\author{
Hülya Öztürk Doğan¹,*, Bingül Kurt Urhan², Tuba Öznülüer Özer³ ${ }^{3}$ Ümit Demir ${ }^{4}$ \\ ${ }^{1}$ Department of Chemistry and Chemical Processing Technologies, Technical Sciences Vocational College, \\ Atatürk University, Erzurum, Turkey 25240 \\ ${ }^{2}$ Department of Nanoscience and Nanoengineering, Nanomaterials Sciences, Atatürk University, \\ Erzurum, Turkey 25240 \\ ${ }^{3}$ Department of Chemistry, Sciences Faculty, Atatürk University, 25240, Erzurum - Turkey \\ ${ }^{4}$ Department of Chemistry, Sciences Faculty, Gebze Technical University, 41400, Kocaeli - Turkey \\ hdogan@atauni.edu.tr
}

\begin{abstract}
In this study, the preparation of tin(II) oxide/reduced graphene oxide ( $\mathrm{SnO} / \mathrm{rGO}$ ) hybrid electrodes was simultaneously performed by a one-pot electrodeposition process for the first time by using a single cell. The morphological and structural characterizations of $\mathrm{SnO} / \mathrm{rGO}$ were performed by scanning electron microscopy (SEM), energy-dispersive X-ray spectrometry (EDS), X-ray photoelectron spectroscopy (XPS), and X-ray diffraction (XRD). Additionally, the electrocatalytic activities of the electrode materials for the determination of DA were tested by the linear sweep voltammetry technique. Furthermore, the amperometric sensing of DA was carried out with a detection limit of $0.32 \mu \mathrm{M}$. The results suggest that our fabricated biosensor exhibited an ultrahigh sensitivity, low detection limit, and excellent selectivity.
\end{abstract}

Keywords: dopamine; graphene; reduced graphene oxide; tin oxide

\section{ЕЛЕКТРОХЕМИСКО ДИЗАЈНИРАЫЕ НА ЕДНА ЕЛЕКТРОХЕМИСКА К'ЕЛИЈА НА ЕЛЕКТРОДИ ИЗРАБОТЕНИ ОД SnO И РЕДУЦИРАН ГРАФЕН ОКСИД ЗА АМПЕРОМЕТРИСКО ОПРЕДЕЛУВАЊЕ НА ДОПАМИН}

Во оваа студија е претставен метод за изработка на хибридни електроди добиени од калај(II) оксид и редуциран графен оксид ( $\mathrm{SnO} / \mathrm{rGO})$ со симултана електродепозиција во еден чекор со употреба на само една електрохемиска ќелија. Морфолошката и структурната карактеризација на SnO/rGO беше извршена со примена на скенирачката електронска микроскопија (SEM), енергетската дисперзивна рендгенска спектрометрија (EDS), рендгенската фотоелектронска спектроскопија (XPS) и рендгенската дифракција (XRD). Притоа, електрокаталитичката активност на електродниот материјал беше тестирана за определување на допамин со употреба на линеарна волтаметрија. Амперометриското определување на допамин се карактеризираше со лимит на детекција од $0,32 \mu \mathrm{M}$. Резултатите од оваа студија сугерираат дека дизајнираниот биосензор покажува висока осетливост, ниска граница на детекција и одлична селективност.

Клучни борови: допамин; графен; редуциран графен оксид; калај(II) оксид

\section{INTRODUCTION}

Dopamine (DA) plays an important role in the central nervous, kidney, and hormonal systems $[1,2]$. Besides, DA is one of the major catecholamines found in the central nervous system that regulates our feelings and thoughts in our body [3, 4]. The deficiency of this substance in the body can lead to symptoms of many bad diseases such as cancer, Parkinson's disease, and cardiovascular diseases [5, 6]. Until now, various techniques such as high-performance liquid chromatography 
(HPLC) [7], spectrophotometry [8], and electrochemical methods [9] have been used for the determination of DA in the presence of AA. However, electrochemical methods are much simpler, cheaper, highly sensitive, and much more environmentally friendly than other traditional methods [10-12]. Moreover, the finding of electrochemical activities of AA and DA has increased the interest in electroanalysis methods in determining AA and DA [13]. However, the co-existence of AA and DA in the metabolic system and the proximity of oxidation potentials in electrochemical fixation make it difficult to separate them potentiometrically [14-16]. To overcome this problem, modified electrodes have been prepared using conductive polymers, metals, or metal oxides with various carbon-based materials, including carbon nanotubes, carbon nanofibers, and graphene $(\mathrm{G})$ used to separate oxidation potentials $[13,17,18]$.

$\mathrm{G}$ is a promising nanomaterial for the formation of nanocomposites with metal oxide due to its economy, ease of functionality with other molecules, and easy synthesis approaches [19-27]. For the synthesis of $\mathrm{G}$, the reduction of graphene oxide (GO) using various techniques such as chemical, electrochemical, hydrothermal, or photochemical is often used [28, 29]. Recently, G-based electrochemical sensors have been widely used for the electrocatalytic oxidation of DA [30-36].

Metal oxides such as $\mathrm{Fe}_{3} \mathrm{O}_{4}, \mathrm{CuO}, \mathrm{TiO}_{2}$, $\mathrm{SnO}_{2}$, and $\mathrm{ZnO}$ can interact with graphene oxide via carboxylic acid functional groups $[37,38]$. On the other hand, tin(II) oxide (SnO) has been studied less extensively and has gained attention due to its natural p-type conductivity, large hole mobility, and high theoretical specific capacity [39]. The $\mathrm{SnO}$ is a semiconductor with a tetragonal crystal structure and has a wide bandgap that has been used as an anode material in lithium batteries, gas sensors, and transparent conductors in solar cells [40]. Besides, SnO nanoparticles have attracted considerable attention, especially due to their high elec- trocatalytic activity in dye removal, as well as their selectivity in determining many biological analytes.

In this study, we aimed to synthesize $\mathrm{SnO} /$ reduced graphene oxide ( $\mathrm{SnO} / \mathrm{rGO}$ ) nanocomposites with a single-step co-electrodeposition method, which is easier and less time-consuming than other methods reported in the literature. Moreover, this technique does not require any complexing agents, binders, and/or toxic reagents. The as-prepared composite electrode was used for the amperometric determination of DA. To the best of our knowledge, the use of the $\mathrm{SnO} / \mathrm{rGO}$ composite electrode prepared by electrochemical codeposition method for electrochemical determination of DA has not been reported in the literature. This work presents a good candidate for developing next-generation bio-sensing applications.

\section{EXPERIMENTAL SECTION}

For the experiments, graphene oxide (GO), tin(II) chloride $\left(\mathrm{SnCl}_{2}\right)$, dopamine (DA), ascorbic acid (AA), uric acid (UA), hydrogen peroxide $\left(\mathrm{H}_{2} \mathrm{O}_{2}\right)$, sodium dihydrogen phosphate $\left(\mathrm{NaH}_{2} \mathrm{PO}_{4}\right)$, and disodium hydrogen phosphate $\left(\mathrm{Na}_{2} \mathrm{HPO}_{4}\right)$ were purchased from Sigma-Aldrich (U.S.A). Electrochemical synthesis of $\mathrm{SnO} / \mathrm{rGO}$ nanocomposites was carried out using BAS $100 \mathrm{i}$ potentiostat. In the three-electrode cell system, $\mathrm{Au}, \mathrm{Pt}$ wire, and $\mathrm{Ag} / \mathrm{AgCl}(3 \mathrm{M} \mathrm{KCl})$ electrodes were used as the working, counter, and reference electrodes, respectively. $\mathrm{SnO} / \mathrm{rGO}$ nanocomposites were prepared by depositing at $-600 \mathrm{mV}$ for 6 minutes. A schematic illustration of the experimental procedure is given in Fig.1. Thanks to electrochemical co-deposition, $\mathrm{Sn}^{2+}$ ions and GO can be deposited simultaneously on the Au electrode surface. While GO is reduced to $\mathrm{rGO}, \mathrm{Sn}^{2+}$ ions and the oxygen groups of GO combine to form $\mathrm{SnO}$. The prepared $\mathrm{SnO} / \mathrm{rGO}$ electrode was used for amperometric detection of DA.
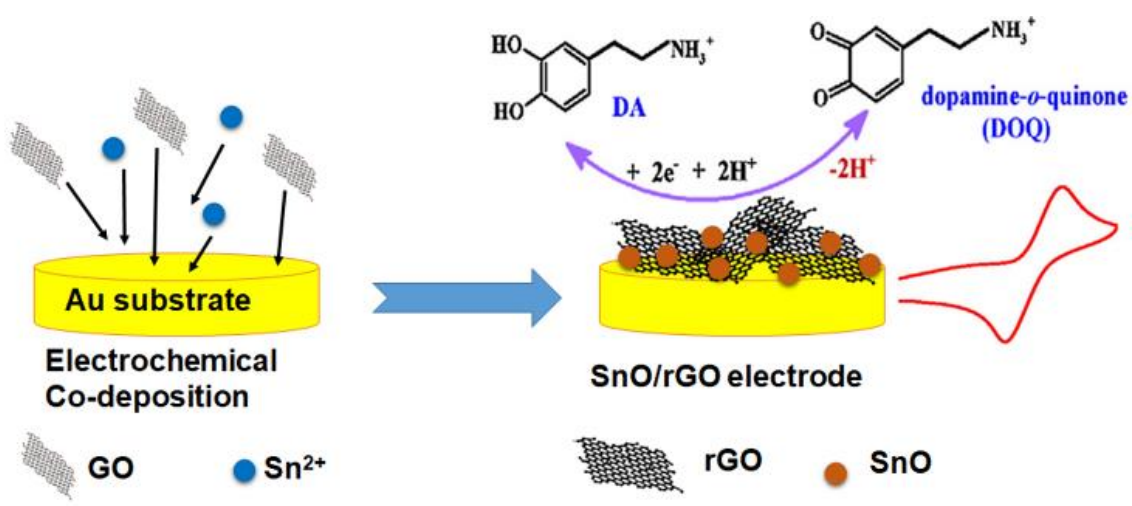

Fig. 1. Schematic illustration of the experimental procedure 
The morphological and analytical characterizations of $\mathrm{SnO} / \mathrm{rGO}$ nanocomposites were performed using scanning electron microscopy (SEM, FEI Quanta), energy dispersion spectroscopy (EDS, combined with FEI Quanta), X-ray photoelectron spectroscopy (XPS, PHI 5000 VersaProbe), and X-ray diffraction spectroscopy (XRD, Rigaku Advance) techniques. The voltammetric detection of DA was performed using linear sweep voltammetry (LSV) and cyclic voltammetry (CV) techniques in phosphate buffer solution (PBS, $0.1 \mathrm{M}$, $\mathrm{pH} 7.0)$.

\section{RESULTS AND DISCUSSION}

\subsection{One-pot electrochemical synthesis of $\mathrm{SnO} / \mathrm{rGO}$ nanocomposites}

For the one-pot electrochemical synthesis of $\mathrm{SnO} / \mathrm{rGO}$ nanostructures on the Au electrode surface, $5 \mathrm{mM} \mathrm{Sn}^{2+}$ and $0.1 \mathrm{mg} / \mathrm{ml} \mathrm{GO} / 0.1 \mathrm{M} \mathrm{KNO}_{3}$ solutions were mixed, and the $\mathrm{CV}$ of the $\mathrm{Au}$ electrode was recorded in the mixture solution (Fig. 2). The $\mathrm{CV}$ was recorded at $0 \mathrm{mV}-(-1000 \mathrm{mV})$ potential region with a scan rate of $100 \mathrm{mV} \mathrm{s}^{-1}$.

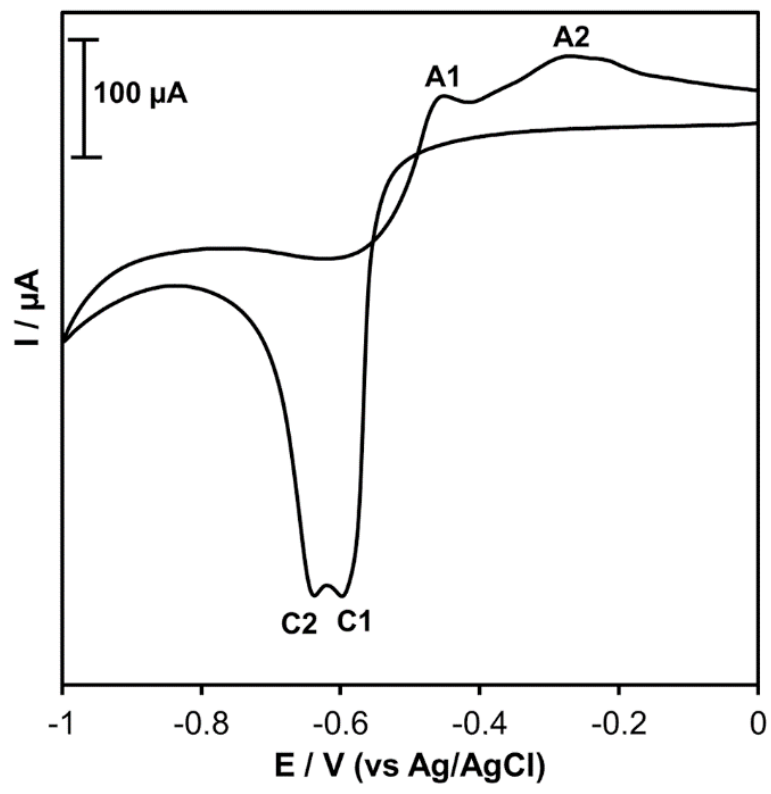

Fig. 2. The CV of Au electrode in the mixed solution of $\mathrm{Sn}^{2+}$ and GO

As can be seen in Figure 2, two reduction peaks (labelled $\mathrm{C}_{1}$ and $\mathrm{C}_{2}$ ) were present in the $\mathrm{CV}$ that corresponded to the reduction of $\mathrm{GO}$ to $\mathrm{rGO}$ (at approximately $-630 \mathrm{mV}$ ) and $\mathrm{Sn}^{2+}$ to $\mathrm{Sn}$ (at approximately $-580 \mathrm{mV}$ ). Both $\mathrm{SnO}$ and $\mathrm{rGO}$ can be simultaneously deposited on the electrode surface at a single potential of about $-600 \mathrm{mV}$.

\subsection{The morphological and analytical characterization of $\mathrm{Au}-\mathrm{SnO} / \mathrm{rGO}$ electrode}

X-ray diffraction (XRD) analysis was performed to determine the crystal orientation of $\mathrm{SnO} / \mathrm{rGO}$ nanostructures. In the XRD pattern of Fig. 3a, the diffraction peaks at $2 \theta=33.2^{\circ}$ and $50.7^{\circ}$ correspond to the $\mathrm{SnO}(110)$ and $\mathrm{SnO}(211)$ structures, respectively. The diffraction peaks occurring at $2 \theta=38,43.7,63.9$, and $76.9^{\circ}$ correspond to (111), (200), (220), and (311) crystal structures of the $\mathrm{Au}$ electrode, respectively. In addition to these peaks XRD diffraction of the (211) crystal structure of $\mathrm{Sn}_{6} \mathrm{O}_{4}(\mathrm{OH})_{4}$, formed as an intermediate product, was also determined. Moreover, the XRD diffraction peak of rGO at approximately $25^{\circ}$ could not be observed since the rGO structures diverged from each other when metal particles are deposited on the G surface in G-metal composites.

XPS analysis generally provides information about the qualitative, quantitative, and chemical structure of the synthesized materials. The XPS spectrum shows both the binding energies $(\mathrm{eV})$ of the X-ray photoelectrons of the elements that make up the synthesized material and the oxidation step with the presence of that element. Moreover, these measurements allow understanding of chemical differences such as metal/metal oxide or carbon/carbonyl. The presence of $\mathrm{C}, \mathrm{O}$, and Sn elements in the survey XPS spectrum recorded for the $\mathrm{SnO} / \mathrm{rGO}$ composite was detected (Fig. 3b). The carbon peak in the survey XPS spectra supported that the electrochemical reduction of GO was successfully achieved. In the XPS spectrum in Figure $3 \mathrm{c}$, the positions of the binding energies of the $\mathrm{Sn} 3 \mathrm{~d}$ peaks (486 eV for $\mathrm{Sn} 3 \mathrm{~d}_{5 / 2}$ and $494.4 \mathrm{eV}$ for $\mathrm{Sn} 3 \mathrm{~d}_{3 / 2}$ ) exactly match the standard data of $\mathrm{SnO}$ [41]. The XPS spectrum of Sn3d confirmed that tin in nanostructures has the $\mathrm{Sn}^{2+}$ oxidation step. On the other hand, the broad peak observed at 530.4 $\mathrm{eV}$ in the XPS spectrum obtained for O1s in Figure $3 \mathrm{~d}$ corresponds to the various bindings of oxygen.

The morphology of as-prepared $\mathrm{SnO} / \mathrm{rGO}$ nanostructures was determined by the SEM technique. The typical morphology of $\mathrm{SnO} / \mathrm{rGO}$ nanostructures electrodeposited from an oxygen saturated solution at a constant potential of -600 $\mathrm{mV}$ on the $\mathrm{Au}$ electrode surface for 6 minutes is shown in Figure 4a. In this SEM image, it is seen that a few squares and rectangular particles of the $\mathrm{SnO}$ structure and a curled structure originating from the graphene structure were formed on the electrode surface. The EDS spectrum of the $\mathrm{SnO} / \mathrm{rGO}$ composite (Fig. 4b) included $\mathrm{C}$ atoms from $\mathrm{rGO}$ and $\mathrm{Sn}$ and $\mathrm{O}$ atoms from $\mathrm{SnO}$. Besides, 
the peak of the Au electrode, which was used as a substrate, is present in the EDS spectra. The EDS spectrum confirmed that an elemental impurityfree $\mathrm{SnO} / \mathrm{rGO}$ composite was synthesized.
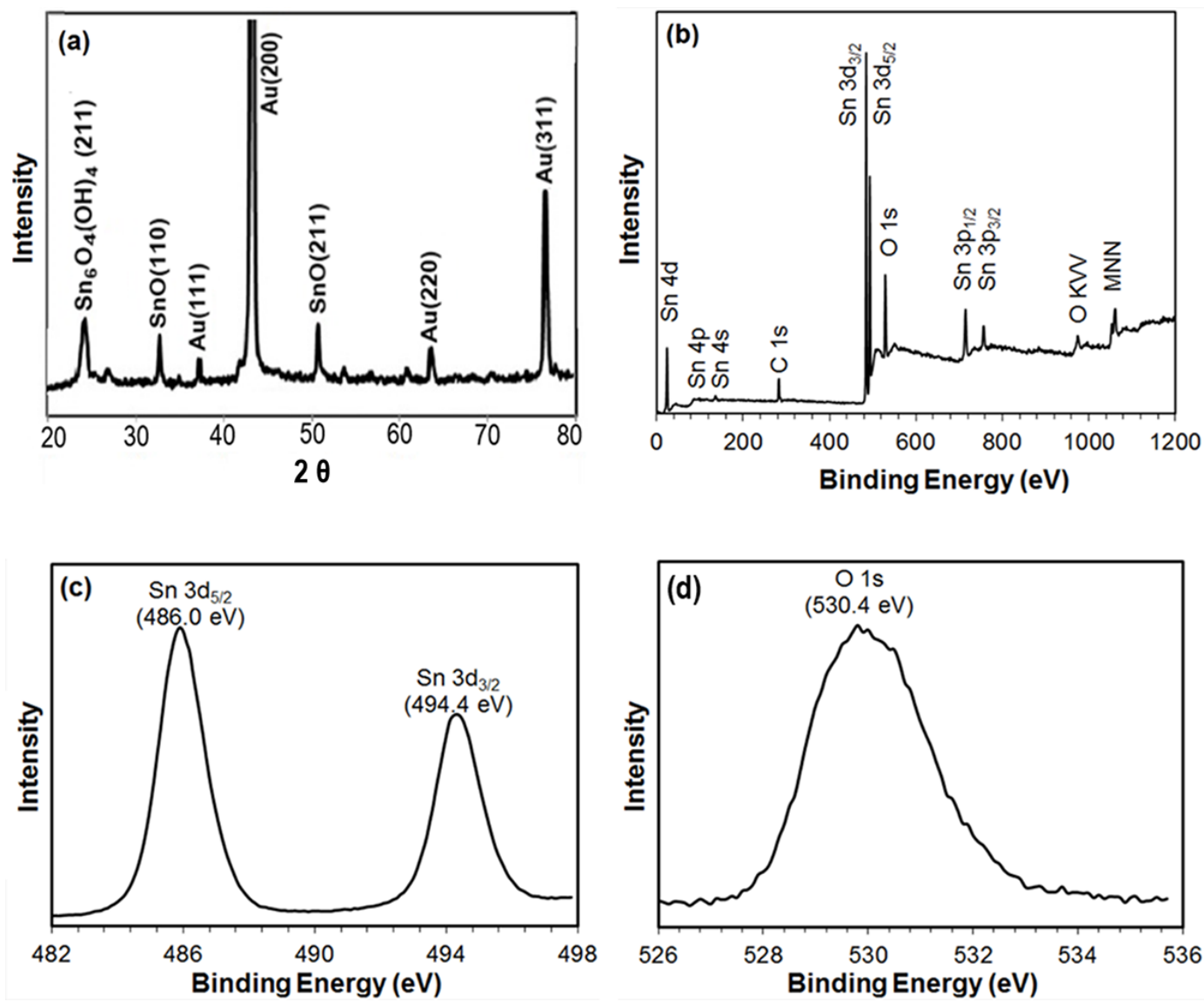

Fig. 3. XRD spectrum (a) and XPS spectra (b-d) of $\mathrm{SnO} / \mathrm{rGO}$
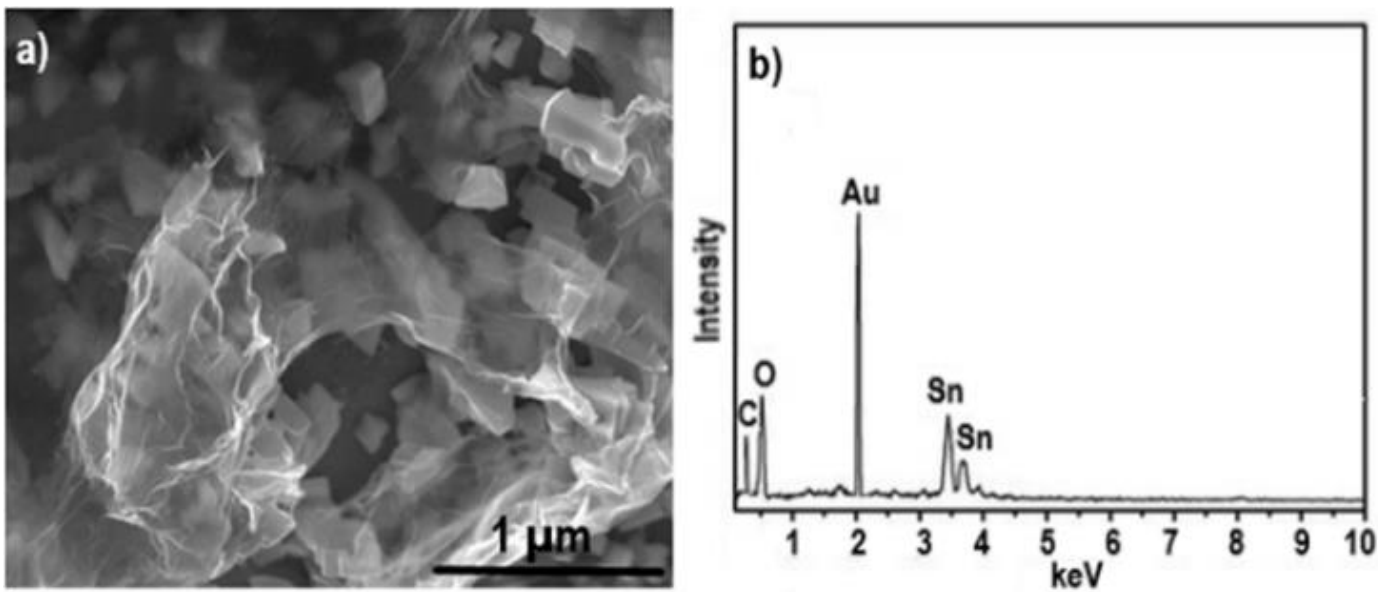

Fig. 4. SEM image (a) and EDS spectrum (b) of $\mathrm{SnO} / \mathrm{rGO}$

\subsection{The amperometric sensing of $D A$ on $\mathrm{Au}-\mathrm{SnO} / \mathrm{rGO}$ electrode}

Firstly, the oxidation potential of DA on the $\mathrm{SnO} / \mathrm{rGO}$ electrode was determined by a voltammetric study. The concentration of DA was chosen as $10.0 \mathrm{mM}$ in all measurements. To determine the electrocatalytic properties of the composite modified $\mathrm{Au}$ electrode, the linear sweep voltammograms (LSVs) for $\mathrm{Au}, \mathrm{SnO}$, and $\mathrm{SnO} / \mathrm{rGO}$ electrodes in $10.0 \mathrm{mM}$ DA solution are shown together in Figure 5a. In these LSVs, a wide oxidation peak 
resulting from the oxidation of DA at a potential value of approximately $300 \mathrm{mV}$ is observed. Also, the composite material exhibited the highest current value and the lowest oxidation potential in the
LSVs. The negative shift in peak potential originates from the electrocatalytic effect of $\mathrm{SnO} / \mathrm{rGO}$. In other words, it perceives more sensitive DA with higher current and with less energy.
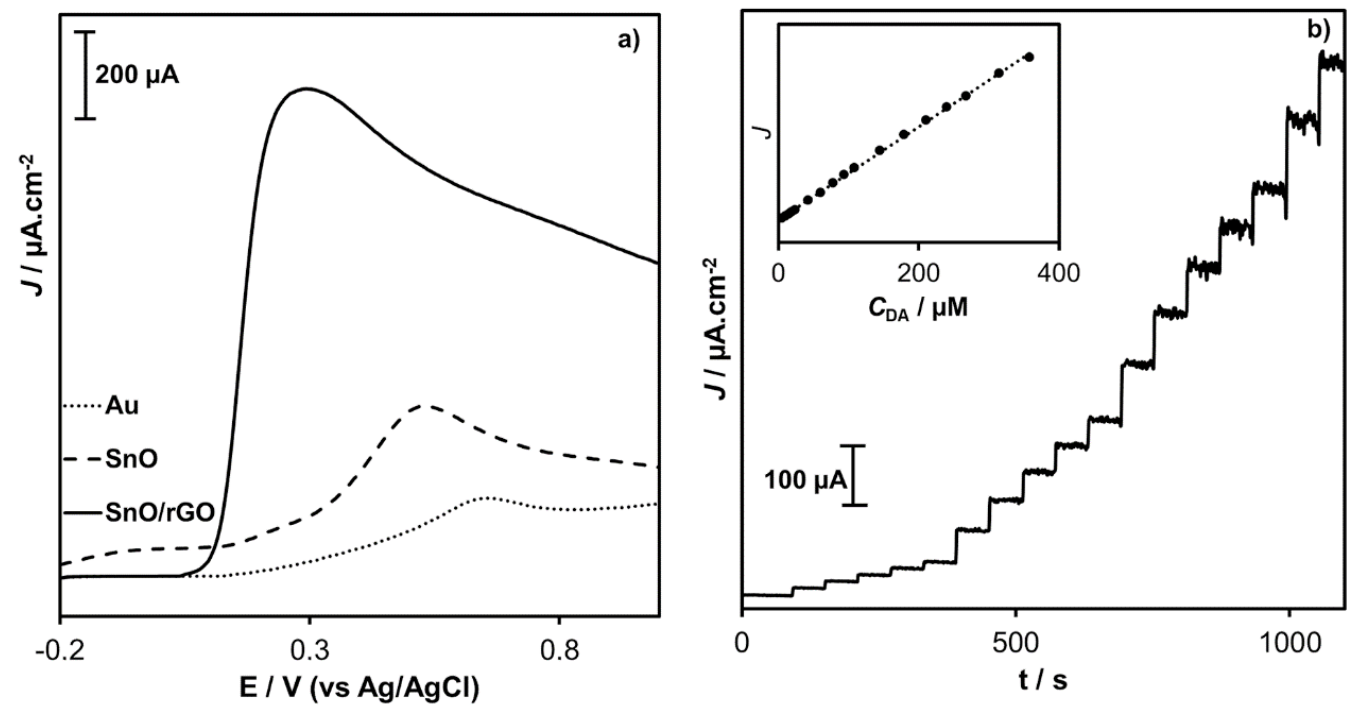

Fig. 5. a. LSVs in $10 \mathrm{mM}$ DA solution on $\mathrm{SnO} / \mathrm{rGO}, \mathrm{SnO}$, and $\mathrm{Au}$ electrodes, $v=50 \mathrm{mV} \mathrm{s}^{-1}$.

b. Current density-time graphic of $\mathrm{SnO} / \mathrm{rGO}$ electrode for different concentrations of DA at $0.3 \mathrm{~V}$.

The graph of current-time (i-t) resulting from the sequential addition of different concentrations of DA to the stirring 0.1 M PBS solution is given in Figure 5b. After DA was added to the $\mathrm{pH}$ 7 solution, the anodic current densities increased gradually to reach a constant value by applying the potential of $0.3 \mathrm{~V}$. As proof that the electrocatalytic response at the nanocomposite electrode is fast, the almost constant current was obtained in less than 3 seconds. When the typical amperometric response of $\mathrm{SnO} / \mathrm{rGO}$ electrode at different concentrations of DA was examined, a fast amperometric response (with a steady-state current of $98 \%$ ) was observed, especially in the low concentration range (Fig. 5.b inset graph). For the amperometric detection of DA, it was determined that the $\mathrm{SnO} / \mathrm{rGO}$ electrode has a high sensitivity of $2.55 \mu \mathrm{A} \mathrm{cm}^{-2} \mathrm{mM}^{-1}$ and shows a linear relationship $(\mathrm{R}=0.9991)$ in a concentration range of $0.5 \mu \mathrm{M}$ to $400 \mu \mathrm{M}$. Besides, the limit of detection (LOD) was calculated to be about $0.32 \mu \mathrm{M}$ when the signal-tonoise ratio was 3 . The detection limit calculated in the literature for different electrodes is compared in Table 1. Compared with the electrodes of Table $1, \mathrm{SnO} / \mathrm{rGO}$ electrode can be used successfully in the amperometric detection of DA due to its relatively lower detection limit.

Detection of DA in biological systems becomes difficult in the presence of AA. Due to the higher amount of AA in the body system, it has become necessary to develop biosensors sensitive to DA. For this purpose, the interference test of the $\mathrm{SnO} / \mathrm{rGO}$ electrode was examined by the sequential addition of biomaterials such as DA, AA, UA, $\mathrm{H}_{2} \mathrm{O}_{2}$, etc. (Fig. 6a). The concentrations of DA, AA, UA, and $\mathrm{H}_{2} \mathrm{O}_{2}$ were selected as $1 \mathrm{mM}, 50$ $\mathrm{mM}, 2 \mathrm{mM}$, and $2 \mathrm{mM}$, respectively. Remarkably, when the DA was added in the PBS, the amperometric current of DA was increased while the current of the interference species was not detected in Fig. 6a. This result showed that $\mathrm{SnO} / \mathrm{rGO}$ electrode had excellent catalytic activity and selective sensing towards DA. Five modified electrodes prepared in the same experimental conditions in the DA solution, recorded LSV measurements to verify the reproducibility of the $\mathrm{SnO} / \mathrm{rGO}$ electrode. The recovery of current densities of the modified electrodes are shown in Figure $6 \mathrm{~b}$. The different $\mathrm{SnO} / \mathrm{rGO}$ electrodes exhibited similar recovery values. To investigate the stability of the electrode, the LSV experiments were conducted for 20 days on the modified electrode. The modified electrode had an initial recovery of the current value of $100 \%$, while this value decreased to $72 \%$ after 20 days (Fig. 6c). Thus, the good stability and reproducibility of the $\mathrm{SnO} / \mathrm{rGO}$ electrode were proved by the obtained results. 
Table 1

Comparison of different electrodes for detection of DA

\begin{tabular}{lccccc}
\hline \hline Electrode & Technique & $\mathrm{pH}$ & $\begin{array}{c}\text { LOD } \\
(\mu \mathrm{M})\end{array}$ & $\begin{array}{c}\text { Linear range } \\
(\mu \mathrm{M})\end{array}$ & Ref \\
\hline $\mathrm{G} / \mathrm{SnO}_{2}$ & $\mathrm{DPV}$ & 6.8 & 1 & $1-20$ & {$[42]$} \\
$\mathrm{GCE} / \mathrm{G} / \mathrm{SnO}_{2}$ & $\mathrm{DPV}$ & 6.5 & 1 & $5-50$ & {$[43]$} \\
Nanostructured gold & $\mathrm{DPV}$ & 7.4 & 5 & $10-100$ & {$[44]$} \\
$\mathrm{G}-\mathrm{Au} \mathrm{NPs}$ & $\mathrm{DPV}$ & 6.0 & 1.86 & $5-1000$ & {$[45]$} \\
$\mathrm{rGO}$ & $\mathrm{CA}$ & 7.0 & 2 & $5-200$ & {$[16]$} \\
$\mathrm{Au}-\mathrm{SnO} / \mathrm{rGO}$ & $\mathrm{CA}$ & 7.0 & 0.32 & $0.5-400$ & This work \\
\hline DPV - Differential pulse voltammetry, CA - Chronoamperometry, G - Graphene, NPs - Nanoparticles, \\
GCE - Glassy carbon electrode, rGO - reduced graphene oxide
\end{tabular}
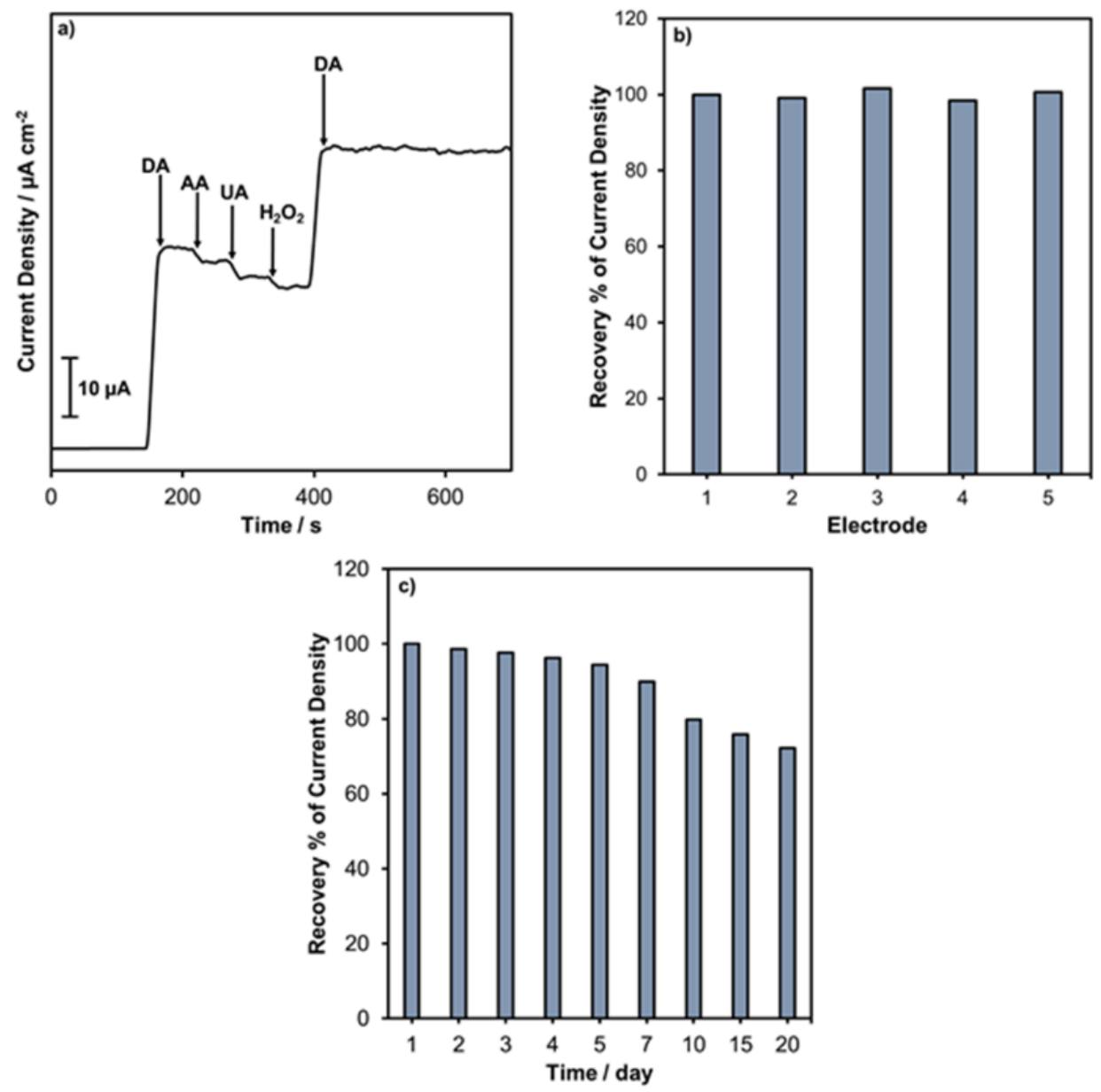

Fig. 6. a. Interference test, b. reproducibility, and c. stability of $\mathrm{SnO} / \mathrm{rGO}$ electrode for DA sensing

The real sample analysis was carried out by measuring the concentration of DA in human serum by the standard addition method. The serum samples were diluted 50 times with PBS buffer before measurement, followed by the addition of known concentrations of DA to the samples, and the recovery rates were calculated. For 1,5 , and 10 $\mathrm{mM}$, the recovery rates were 98.6, 99.4, and $100.1 \%$ with an average of 4 measurements, respectively, implying a hopeful biosensor applica- tion of the $\mathrm{SnO} / \mathrm{rGO}$ electrode in amperometric sensing of DA in real samples.

\section{CONCLUSION}

The Au electrode was successfully modified with $\mathrm{SnO} / \mathrm{rGO}$ composite by applying a one-pot constant potential from the solution mixture containing $\mathrm{Sn}^{2+}$ and GO. The $\mathrm{SnO}$ and rGO structures in the nanocomposite were supported by analytical 
and morphological characterizations. Compared to $\mathrm{Au}$ and $\mathrm{SnO}$ electrodes, the lower oxidation potential and high current density of DA on the $\mathrm{SnO} / \mathrm{rGO}$ electrode were confirmed by LSV results. In addition, the $\mathrm{SnO} / \mathrm{rGO}$ modified electrode was used for the amperometric determination of DA. Amperometric studies revealed that DA can be detected by the large linearity (with $0.5-400 \mu \mathrm{M}$ ) and low LOD (with $0.32 \mu \mathrm{M}$ ). Moreover, the $\mathrm{SnO} / \mathrm{rGO}$ electrode exhibited high selectivity for DA in the presence of interference species, good reproducibility, and relatively long-term stability. This study shows that the as-prepared $\mathrm{SnO} / \mathrm{rGO}$ nanocomposite electrode has great potential for the sensitive detection of dopamine in real sample analysis.

Acknowledgements. This work was supported by Scientific Research Projects of Atatürk University (Project No: FBA-2018-6477).

\section{REFERENCES}

[1] Ş. Sağlam, A. Arman, A. Üzer, B. Ustamehmetoğlu, E. Sezer, R. Apak, Selective electrochemical determination of dopamine with molecularly imprinted poly(carbazoleco-aniline) electrode decorated with gold nanoparticles, Electroanalysis, 32, 964-967 (2020). DOI: https://doi.org/10.1002/elan.201900646.

[2] R. Zhang, G. Di Jin, D. Chen, X. Y. Hu, Simultaneous electrochemical determination of dopamine, ascorbic acid and uric acid using poly(acid chrome blue K) modified glassy carbon electrode, Sensors and Actuators B: Chem. 138, 174-181 (2009). DOI: https://doi.org/10.1016/j.snb.2008.12.043.

[3] B. Habibi, M. Jahanbakhshi, M. H. Pournaghi-Azar, Simultaneous determination of acetaminophen and dopamine using SWCNT modified carbon-ceramic electrode by differential pulse voltammetry, Electrochim. Acta., 56, 2888-2894 (2011).

DOI: https://doi.org/10.1016/j.electacta.2010.12.079.

[4] O. Arrigoni, M. C. De Tullio, Ascorbic acid: much more than just an antioxidant, Biochim. Biophys. Acta - Gen. Subj. 1569, 1-9 (2002).

DOI: https://doi.org/10.1016/S0304-4165(01)00235-5.

[5] E. Fazio, S. Spadaro, M. Bonsignore, N. Lavanya, C. Sekar, S. G. Leonardi, G. Neri, F. Neri, Molybdenum oxide nanoparticles for the sensitive and selective detection of dopamine, J. Electroanal. Chem. 814, 91-96 (2018). DOI: https://doi.org/10.1016/j.jelechem.2018.02.051.

[6] S. Lakard, I. A. Pavel, B. Lakard, Electrochemical biosensing of dopamine neurotransmitter: A review. Biosensors, 11, 179 (2021).

DOI: https://doi.org/10.3390/bios11060179.

[7] M. A. Fotopoulou, P. C. Ioannou, Post-column terbium complexation and sensitized fluorescence detection for the determination of norepinephrine, epinephrine and dopamine using high-performance liquid chromatography, Anal. Chim. Acta, 462, 179-185 (2002). DOI: https://doi.org/10.1016/S0003-2670(02)00312-4.

[8] J. J. Feng, H. Guo, Y. F. Li, Y. H. Wang, W. Y. Chen, A. J. Wang, Single molecular functionalized gold nanoparticles for hydrogen-bonding recognition and colori- metric detection of dopamine with high sensitivity and selectivity, ACS Appl. Mater. Interfaces, 5, 1226-1231 (2013). DOI: https://doi.org/10.1021/am400402c.

[9] H. Ö. Doğan, B. K. Urhan, E. Çepni, M. Eryiğit, Simultaneous electrochemical detection of ascorbic acid and dopamine on $\mathrm{Cu}_{2} \mathrm{O} / \mathrm{CuO}$ /electrochemically reduced graphene oxide (CuxO/ERGO)-nanocomposite-modified electrode, Microchem. J., 150, 104157 (2019). DOI: https://doi.org/10.1016/j.microc.2019.104157.

[10] K. Jackowska, P. Krysiński, New trends in the electrochemical sensing of dopamine, Anal. Bioanal. Chem. 405, 3753-3771n (2013). DOI: https://doi.org/10.1007/s00216-012-6578-2.

[11] M. Kwak, S. Lee, D. Kim, S. K. Park, Y. Piao, Facile synthesis of Au-graphene nanocomposite for the selective determination of dopamine, J. Electroanal. Chem. 776, 66-73 (2016). DOI: https://doi.org/10.1016/j.jelechem.2016.06.047.

[12] P. Ramu, S. P. Vimal, P. Suresh, U. Saravanakumar, V. Sethuraman, S. Anandhavelu, electrochemically deposited porous graphene-polypyrrole-polyphenol oxidase for dopamine biosensor, Electroanalysis, 33, 774-780 (2020). DOI: https://doi.org/10.1002/elan.202060400.

[13] A. Kutluay, M. Aslanoglu, An electrochemical sensor prepared by sonochemical one-pot synthesis of multiwalled carbon nanotube-supported cobalt nanoparticles for the simultaneous determination of paracetamol and dopamine, Anal. Chim. Acta, 839, 59-66 (2014). DOI: https://doi.org/10.1016/j.aca.2014.05.018.

[14] G. Hu, Y. Guo, S. Shaoa, Simultaneous determination of dopamine and ascorbic acid using the nano-gold selfassembled glassy carbon electrode, Electroanalysis, 21, 1200-1206 (2009). DOI: https://doi.org/10.1002/elan.200804510.

[15] Y. Wang, Y. Li, L. Tang, J. Lu, J. Li, Application of graphene-modified electrode for selective detection of dopamine, Electrochem. commun. 11, 889-892 (2009). DOI: https://doi.org/10.1016/j.elecom.2009.02.013.

[16] S. Palanisamy, S. Ku, S. M. Chen, Dopamine sensor based on a glassy carbon electrode modified with a reduced graphene oxide and palladium nanoparticles composite, Microchim. Acta, 180, 1037-1042 (2013). DOI: https://doi.org/10.1007/s00604-013-1028-1.

[17] H. Ö. Doğan, D. Ekinci, Ü. Demir, Atomic scale imaging and spectroscopic characterization of electrochemically reduced graphene oxide, Surf. Sci. 611, 54-59 (2013). DOI: https://doi.org/10.1016/j.susc.2013.01.014.

[18] V. Kathiresan, D. Thirumalai, T. Rajarathinam, M. Yeom, J. Lee, S. Kim, J. H. Yoon, S. C. Chang, A simple one-step electrochemical deposition of bioinspired nanocomposite for the non-enzymatic detection of dopamine, J. Anal. Sci. Technol. 12, 5 (2021). DOI: https://doi.org/10.1186/s40543-021-00260-y.

[19] B. K. Urhan, T. Öznülüer, Ü. Demir, H. Ö. Doğan, Onepot electrochemical synthesis of lead oxideelectrochemically reduced graphene oxide nanostructures and their electrocatalytic applications, IEEE Sens. J. 19, 4781-4788 (2019). DOI: https://doi.org/10.1109/JSEN.2019.2904738.

[20] B. K. Urhan, H. Ö. Doğan, T. Ö. Özer, Ü. Demir, Onepot electrochemical synthesis of $\mathrm{Ni}$ nanoparticlesdecorated electroreduced graphene oxide for improved NADH sensing, Electroanalysis, 32, 2323-2329 (2020). DOI: https://doi.org/10.1002/elan.202060117. 
[21] H. Ö. Doğan, E. Çepni, B. K. Urhan, M. Eryiğit, Nonenzymatic amperometric detection of $\mathrm{H}_{2} \mathrm{O}_{2}$ on one-step electrochemical fabricated $\mathrm{Cu}_{2} \mathrm{O}$ /electrochemically reduced graphene oxide nanocomposite, Chemistry Select., 4, 8317-8321 (2019). DOI: https://doi.org/10.1002/slct.201901588.

[22] M. Eryiğit, E. Çepni, B. K. Urhan, H. Ö. Doğan, T. Ö. Özer, Nonenzymatic glucose sensor based on poly $(3,4-$ ethylene dioxythiophene)/electroreduced graphene oxide modified gold electrode, Synth. Met. 268, 116488 (2020). DOI: https://doi.org/10.1016/j.synthmet.2020.116488.

[23] B. K. Urhan, Ü. Demir, T. Ö. Özer, H. Ö. Doğan, Electrochemical fabrication of $\mathrm{Ni}$ nanoparticles-decorated electrochemically reduced graphene oxide composite electrode for non-enzymatic glucose detection, Thin Solid Films. 693, 137695 (2020). DOI: https://doi.org/10.1016/j.tsf.2019.137695.

[24] M. Eryiğit, E. Temur, T.Ö. Özer, H.Ö. Doğan, Electrochemical fabrication of Prussian blue nanocube-decorated electroreduced graphene oxide for amperometric sensing of NADH, Electroanalysis, 31, 905-912 (2019). DOI: https://doi.org/10.1002/elan.201800830.

[25] T. Öznülüer, Ü. Demir, H. Ö. Doğan, Fabrication of underpotentially deposited $\mathrm{Cu}$ monolayer/electrochemically reduced graphene oxide layered nanocomposites for enhanced ethanol electro-oxidation, Appl. Catal. B Environ. 235, 56-65 (2018).

DOI: https://doi.org/10.1016/j.apcatb.2018.04.065.

[26] H. Ö. Doğan, Ethanol electro-oxidation in alkaline media on $\mathrm{Pd} /$ electrodeposited reduced graphene oxide nanocomposite modified nickel foam electrode, Solid State Sci. 98, 106029 (2019). DOI: https://doi.org/10.1016/j.solidstatesciences.2019.106029.

[27] S. Pei, H. M. Cheng, The reduction of graphene oxide, Carbon., 50, 3210-3228 (2012). DOI: https://doi.org/10.1016/j.carbon.2011.11.010.

[28] S. Thakur, N. Karak, Alternative methods and naturebased reagents for the reduction of graphene oxide: A review, Carbon, 94, 224-242 (2015). DOI: https://doi.org/10.1016/j.carbon.2015.06.030.

[29] V. V. Sharma, I. Gualandi, Y. Vlamidis, D. Tonelli, Electrochemical behavior of reduced graphene oxide and multiwalled carbon nanotubes composites for catechol and dopamine oxidation, Electrochim. Acta. 246, 415-423 (2017). DOI: https://doi.org/10.1016/j.electacta.2017.06.071.

[30] G. J. Rani, K. J. Babu, G. G. kumar, M. A. J. Rajan, Watsonia meriana flower like $\mathrm{Fe}_{3} \mathrm{O}_{4} /$ reduced graphene oxide nanocomposite for the highly sensitive and selective electrochemical sensing of dopamine, J. Alloys Compd. 688, 500-512 (2016).

DOI: https://doi.org/10.1016/j.jallcom.2016.07.101.

[31] R. Sivasubramanian, P. Biji, Preparation of copper (I) oxide nanohexagon decorated reduced graphene oxide nanocomposite and its application in electrochemical sensing of dopamine, Mater. Sci. Eng. B: Solid-State Mater. Adv. Technol. 210, 10-18 (2016). DOI: https://doi.org/10.1016/j.mseb.2016.04.018.

[32] H. Bagheri, N. Pajooheshpour, B. Jamali, S. Amidi, A. Hajian, H. Khoshsafar, A novel electrochemical platform for sensitive and simultaneous determination of dopamine, uric acid and ascorbic acid based on $\mathrm{Fe}_{3} \mathrm{O}_{4-}$ $\mathrm{SnO}_{2}-\mathrm{Gr}$ ternary nanocomposite, Microchem. J. 131, 120-129 (2017).

DOI: https://doi.org/10.1016/j.microc.2016.12.006.
[33] A. Numan, M. M. Shahid, F. S. Omar, K. Ramesh, S. Ramesh, Facile fabrication of cobalt oxide nanograindecorated reduced graphene oxide composite as ultrasensitive platform for dopamine detection, Sensors and Actuators B: Chem. 238, 1043-1051 (2017). DOI: https://doi.org/10.1016/j.snb.2016.07.111.

[34] X. W. Liu, J. J. Mao, P. De Liu, X. W. Wei, Fabrication of metal-graphene hybrid materials by electroless deposition, Carbon, 49, 477-483 (2011). DOI: https://doi.org/10.1016/j.carbon.2010.09.044.

[35] J. Tian, W. Wu, A novel preparation of water-dispersed graphene and their application to electrochemical detection of dopamine, Adv. Powder Technol. 32, 619-629 (2021). DOI: https://doi.org/10.1016/j.apt.2021.01.011.

[36] M. Eryiğit, E. P. Gür, M. Hosseinpour, T. Ö. Özer, H. Ö. Doğan, Amperometric detection of dopamine on Prussian blue nanocube-decorated electrochemically reduced graphene oxide hybrid electrode, Mater. Today Proc. 46, 6991-6995 (2021). DOI: https://doi.org/10.1016/j.matpr.2021.03.277.

[37] X. Zhang, Y. C. Zhang, L. X. Ma, One-pot facile fabrication of graphene-zinc oxide composite and its enhanced sensitivity for simultaneous electrochemical detection of ascorbic acid, dopamine and uric acid, Sensors and Actuators B: Chem. 227, 488-496 (2016). DOI: https://doi.org/10.1016/j.snb.2015.12.073.

[38] S. T. Chang, I. C. Leu, M. H. Hon, Preparation and characterization of nanostructured tin oxide films by electrochemical deposition, Electrochem. Solid-State Lett. 5, C71 (2002). DOI: https://doi.org/10.1149/1.1485808.

[39] S. Kaizra, Y. Louafi, B. Bellal, M. Trari, G. Rekhila, Electrochemical growth of tin(II) oxide films: Application in photocatalytic degradation of methylene blue, Mater. Sci. Semicond. Process. 30, 554-560 (2015). DOI: https://doi.org/10.1016/j.mssp.2014.10.045.

[40] J. M. Themlin, M. Chtaïb, L. Henrard, P. Lambin, J. Darville, J.M. Gilles, Characterization of tin oxides by x-ray-photoemission spectroscopy, Phys. Rev. B. 46, 2460-2466 (1992). DOI: https://doi.org/10.1103/PhysRevB.46.2460.

[41] Y. L. Xie, J. Yuan, H. L. Ye, P. Song, S. Q. Hu, Facile ultrasonic synthesis of graphene/ $\mathrm{SnO}_{2}$ nanocomposite and its application to the simultaneous electrochemical determination of dopamine, ascorbic acid, and uric acid, J. Electroanal. Chem. 749, 26-30 (2015). DOI: https://doi.org/10.1016/j.jelechem.2015.04.035.

[42] R. Nurzulaikha, H. N. Lim, I. Harrison, S. S. Lim, A. Pandikumar, N. M. Huang, S. P. Lim, G. S. H. Thien, N. Yusoff, I. Ibrahim, Graphene/ $\mathrm{SnO}_{2}$ nanocompositemodified electrode for electrochemical detection of dopamine, Sens. Bio-Sensing Res. 5, 42-49 (2015). DOI: https://doi.org/10.1016/j.sbsr.2015.06.002.

[43] B. J. Plowman, M. Mahajan, A. P. O’Mullane, S. K. Bhargava, Electrochemical detection of dopamine and cytochrome c at a nanostructured gold electrode, Electrochim. Acta, 55, 8953-8959 (2010). DOI: https://doi.org/10.1016/j.electacta.2010.08.045.

[44] J. Li, J. Yang, Z. Yang, Y. Li, S. Yu, Q. Xu, X. Hu, Graphene-Au nanoparticles nanocomposite film for selective electrochemical determination of dopamine, Anal. Methods, 4, 1725-1728 (2012). DOI: https://doi.org/10.1039/c2ay05926f. 